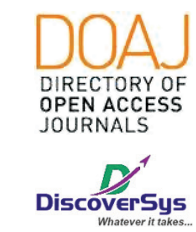

Published by DiscoverSys

\title{
Rasio Mean Platelet Volume (MPV) terhadap hitung trombosit dan Interleukin-6 (IL-6) sebagai prediktor awal kematian pada sepsis neonatal di RSUP Sanglah, Bali, Indonesia
}

\author{
I Putu Sidhi Rastu Karyana, ${ }^{1 *}$ Ni Nyoman Mahartini, ${ }^{2}$ I Made Kardana ${ }^{3}$
}

\section{ABSTRACT}

\begin{abstract}
Background: Neonatal sepsis is a clinical syndrome in infants aged less than 28 days that arises from a systemic inflammatory response (SIRS) by various infectious causes. Both Interleukin-6 (IL-6) and Mean Platelet Volume (MPV) levels are known to play an important role in worsening neonatal sepsis. This study aims to determine the relationship between MPV ratio to platelet count and IL-6 as an early predictor of death in neonatal sepsis at Sanglah General Hospital, Bali, Indonesia.

Methods: This prospective observational cohort study was conducted from November 2019 to February 2020 at Sanglah General Hospital Denpasar, involving 54 pediatric patients diagnosed with neonatal sepsis for less than 28 days. The research samples were collected consecutively. Statistical analysis is the survival analysis, Receiver Operating Characteristic (ROC) curve, linear regression, and Fisher exact test using SPSS software version 20 for Windows.
\end{abstract}

Results: Most of the respondents had an average age of $3.46 \pm 7,065$ days, followed by male gender (72.22\%), SNAD type of sepsis (88.89\%), birth weight 2,126.6 \pm 794.1 grams, normal birth weight (38.89\%), and premature birth (61.11\%). The mean MPV level in all subjects was $7.11 \pm$ $1.85 \mathrm{fL}$, followed by a platelet count $(218.511 \pm 121.085)$ cells/ $\mu \mathrm{L}, \mathrm{MPV} /$ PLT ratio $(5.404 \pm 5.351)$, IL-6 levels $(215.32 \pm 444,48 \mathrm{pg} / \mathrm{mL})$, and as much as $12.95 \%$ died within 28 days of treatment. The results of the survival analysis showed a significant relationship between the MPV value (Cut-off: 6.745 (AUC: 0.650: HR: 4.353; $p=0.033$ ) and the MPV/PLT ratio (Cut-off: 3.73; AUC: 0.690; HR: 4.535; $p=0.033$ ) as an early predictor of mortality in neonatal sepsis at Sanglah General Hospital, Bali, Indonesia. Conclusion: MPV/PLT and MPV ratios can be used as predictors of early mortality within 28 days in patients with clinical neonatal sepsis at Sanglah General Hospital, Bali, Indonesia.

Keywords: Neonatal Sepsis, MPV/PLT Ratio, IL-6, Predictors of Death

Cite This Article: Karyana, I.P.S.R., Mahartini, N.N., Kardana, I.M. 2020. Rasio Mean Platelet Volume (MPV) terhadap hitung trombosit dan Interleukin-6 (IL-6) sebagai prediktor awal kematian pada sepsis neonatal di RSUP Sanglah, Bali, Indonesia. Intisari Sains Medis 11(2): 839-844. DOI: 10.15562/ism.v11i2.755

\section{ABSTRAK}

Latar Belakang: Sepsis neonatal adalah sindrom klinis pada bayi berumur kurang dari 28 hari yang timbul akibat respon inflamasi sistemik (SIRS) oleh berbagai penyebab infeksi. Kadar Interleukin-6 (IL-6) maupun Mean Platelet Volume (MPV) diketahui berperan penting terhadap perburukan pada sepsis neonatal. Penelitian ini bertujuan untuk mengetahui hubungan rasio MPV terhadap hitung trombosit maupun IL-6 sebagai prediktor awal kematian pada sepsis neonatal di RSUP Sanglah, Bali, Indonesia.

Metode: Penelitian Kohort prospektif observasional dilakukan sejak November 2019 sampai Februari 2020 di RSUP Sanglah Denpasar dengan melibatkan 54 pasien anak yang terdiagnosis sepsis neonatal kurang dari 28 hari. Sampel penelitian dikumpulkan secara konsekutif. Analsis statistik yaitu dengan analisis kesintasan, kurva Receiver Operating Characteristic (ROC), regresi linier, dan tes Fisher exact menggunakan piranti lunak SPSS versi 20 untuk Windows.
Hasil: Sebagian besar responden rata-rata berusia 3.46 \pm 7.065 hari, diikuti dengan jenis kelamin laki-laki (72,22\%), jenis sepsis tipe SNAD $(88,89 \%)$, berat lahir $2.126,6 \pm 794,1$ gram, berat badan lahir normal (38,89\%), dan lahir prematur (61,11\%). Rerata kada MPV pada seluruh subjek adalah $7,11 \pm 1,85 \mathrm{fL}$, diikuti dengan hitung trombosit (218.511 \pm 121.085$) \mathrm{sel} / \mu \mathrm{L}$, rasio MPV/PLT $(5,404 \pm 5,351)$, kadar IL-6 (215,32 $\pm 444,48 \mathrm{pg} / \mathrm{mL})$, dan sebanyak $12,95 \%$ meninggal dalam 28 hari perawatan. Hasil analisis kesintasan menunjukkan hubungan bermakna antara nilai MPV (Cut-off: 6,745 (AUC: 0,650: HR: 4,353; $p=0,033$ ) dan rasio MPV/PLT (Cut-off: 3,73; AUC: 0,690; HR: 4,535; $p=0,033)$ sebagai prediktor awal kematian pada sepsis neonatal di RSUP Sanglah, Bali, Indonesia.

Kesimpulan: Rasio MPV/PLT dan MPV dapat digunakan sebagai prediktor awal kematian dalam 28 hari pada pasien dengan klinis sepsis neonatal di RSUP Sanglah, Bali, Indonesia
Patologi Klinik, Fakultas Kedokteran, Universitas Udayana, RSUP Sanglah, Bali, Indonesia;

rastukaryana21@gmail.com
Kata Kunci: Sepsis Neonatal, Rasio MPV/PLT, IL-6, Prediktor Kematian

Cite Pasal Ini: Karyana, I.P.S.R., Mahartini, N.N., Kardana, I.M. 2020. Rasio Mean Platelet Volume (MPV) terhadap hitung trombosit dan Interleukin-6 (IL-6) sebagai prediktor awal kematian pada sepsis neonatal di RSUP Sanglah, Bali, Indonesia. Intisari Sains Medis 11(2): $839-844$. DOl: 10.15562/ism.v11i2.755 


\section{PENDAHULUAN}

Sepsis neonatal adalah sindrom klinis pada bayi berumur 28 hari atau kurang yang timbul akibat respon inflamasi sistemik (SIRS) akibat infeksi bakteri, virus, jamur, atau parasit. ${ }^{1}$ Angka kematian neonatus di Indonesia tahun 2017 yaitu 15/1000 kelahiran hidup dengan sepsis menjadi penyebab keempat kematian (13\%). ${ }^{2}$ di RSUP Sanglah, kejadian sepsis neonatal sebesar 5\% dengan tingkat kematian sebesar $30,4 \%$ pada tahun 2012. ${ }^{3}$

Disregulasi respon imun alamiah terhadap agen infeksi menginisiasi terjadinya sepsis. Interleukin-6 (IL-6) adalah sitokin pro-inflamasi yang dikeluarkan sel yang berefek pada berbagai sel dan organ, termasuk trombosit dan indeks trombosit. ${ }^{4-6}$ Akan tetapi, dewasa ini belum terdapat studi yang meneliti hubungan IL-6 dengan trombosit pada neonatus.

Penggunaan hitung trombosit dan indeks trombosit pada pasien sepsis telah diteliti dan bermakna sebagai marker prognostik. ${ }^{7}$ Mean Platelet Volume (MPV) mencerminkan ukuran trombosit yang membesar jika terjadi aktivasi. ${ }^{8}$ Penelitian Kim $\mathrm{CH}$ et al. menyatakan peningkatan MPV sebesar $0,8 \mathrm{fL}$ selama 72 jam pertama meningkatkan risiko kematian 1,9 kali lipat selama 28 hari. ${ }^{8}$ Sedangkan penelitian yang dilakukan oleh $\mathrm{Oh}$ GH et al. menyatakan rasio MPV terhadap hitung trombosit dengan formula [MPV/(hitung trombosit/1000)] $\mathrm{x} 100$, atau bisa disingkat rasio MPV/PLT, yang tinggi dalam 24 jam pertama pada pasien sepsis berat dewasa meningkatkan risiko kematian 28 hari sebesar 2,7 kali lipat.9 Data penelitian yang menilai hitung trombosit dan MPV sebagai faktor risiko kematian pada neonatus dengan sepsis masih sangat terbatas dilakukan, berbeda halnya dengan parameter hematologi lain seperti rasio neutrophil dan platelet terhadap limfosit pada kasus sepsis maupun keganasan. ${ }^{10-12}$ padahal pemeriksaan ini adalah pemeriksaan yang cepat, mudah diakses, bersamaan dengan pemeriksaan Darah Lengkap (DL), dan terjangkau terutama untuk negara berkembang.

Berdasarkan latar belakang diatas, maka sangat perlu untuk dilakukan penelitian tentang peran rasio MPV terhadap hitung trombosit (MPV/PLT) sebagai marker prognostik awal kematian dalam 28 hari pasien neonatus dengan sepsis dan korelasinya dengan kadar IL-6. Tujuan dari penelitian ini adalah untuk mengetahui apakah rasio MPV/ PLT, MPV, dan hitung trombosit dapat digunakan sebagai prediktor kematian pasien sepsis neonatal dan untuk mengetahui apakah rasio MPV/PLT ini berkorelasi positif dengan IL-6.

\section{METODE}

Penelitian ini merupakan penelitian kohort prospektif observasional yang dilakukan di Instalasi Gawat Darurat (IGD) pediatri, NICU, ruang observasi neonatus, dan laboratorium RSUP Sanglah Denpasar dari bulan November 2019 sampai Februari 2020. Sebanyak 54 pasien dengan diagnosis sepsis neonatal secara klinis diikuti dari pertama kali diagnosis klinis ditegakkan sampai 28 hari. Pengumpulan sampel dilakukan secara konsekutif. Kriteria inklusi adalah semua pasien dengan diagnosis klinis sepsis neonatal saat ditegakkan dan keluarga setuju untuk diikutkan dalam penelitian. Kriteria eksklusi adalah: kesalahan pre-analitik, analitik, dan pasca analitik yang menyebabkan hitung trombosit, MPV, dan IL-6 rendah atau tinggi palsu; pasien mengonsumsi obat-obatan yang dapat memicu trombositopenia yaitu obat-obatan kemoterapi, diuretic, thiazide, etanol, tolbutamide, bleomycin, quinidine, quinine, NSAIDs, sulfonamide, sedatif, antikonvulsan, inhibitor GPIIb/IIIa, abciximab, gold salts, procainamide, dan heparin: ${ }^{10}$ pasien dengan dugaan klinis memiliki penyakit yang memicu trombositopenia selain sepsis, yaitu Hemolytic Disease of Newborn, kelainan kongenital mayor, leukemia kongenital, dan penyakit metabolik; ${ }^{11}$ pasien loss of follow up atau pulang paksa; pasien yang meninggal bukan karena sepsis.

Subyek penelitian dibagi menjadi dua kelompok dengan jumlah yang sama, yaitu kelompok berisiko tinggi dengan rasio MPV/PLT > 3,71 dan kelompok berisiko rendah dengan rasio MPV/PLT $\leq 3,71$. Keluaran yang diobservasi dalam 28 hari adalah apakah pasien bertahan hidup atau tidak. Pemeriksaan IL-6 menggunakan sampel serum yang diambil bersamaan dengan pemeriksaan darah lengkap saat diagnosis klinis sepsis neonatal ditegakkan.

Pemeriksaan hitung trombosit dan MPV menggunakan Hemato analyzer Cell-dyn Ruby Abbott@, sementara pemeriksaan IL-6 menggunakan kit ELISA human IL-6 dari Elabscience@. Penjaminan mutu untuk Cell-dyn Ruby dilakukan secara harian dengan interpretasi kontrol dalam grafik Levey-Jenning menaati aturan Westgard Rule. Sementara itu, penjaminan mutu kit ELISA human IL-6 dengan duplikasi within run 8 sampel untuk mendapatkan impresisi dalam Standar Deviasi (SD) dan Coefficient Variation (CV).

Analisis statistik menggunakan analisis kesintasan dengan Kaplan-Meier. Korelasi antara IL-6 dengan rasio MPV/PLT menggunakan analisis korelasi Pearson jika data berdistribusi normal atau korelasi Spearman jika data berdistribusi tidak normal. Analisis Receiver Operating Curve (ROC) dikerjakan untuk menentukan cut off MPV, hitung 
trombosit, dan cut off rasio MPV/PLT berdasarkan hasil penelitian. Variabel pengganggu pada penelitian, yaitu SNAD, prematuritas, dan berat bayi lahir. Analisis dengan regresi linier pada variabel numerik (berat bayi lahir) dan Chi Square atau Fisher exact pada variabel kategorikal (SNAD dan prematuritas) dilakukan untuk menentukan apakah variabel-variabel ini memiliki makna secara statistik (control by analysis). Data dianalisis dengan piranti lunak SPSS versi 20 untuk Windows.

\section{HASIL}

Hasil penelitian menunjukkan bahwa sebanyak 72,22\% pasien berjenis kelamin laki-laki dan 27,8\% berjenis kelamin perempuan (Tabel 1). Pasien SNAD ditemukan sebanyak $88,89 \%$ dengan rata-rata berat lahir $2.126,6 \pm 794,1$ gram dimana sebanyak 21 neonatus $(38,89 \%)$ memiliki berat lahir normal, 33 neonatus $(61,11 \%)$ prematur, dan sebanyak 7 neonatus (12,96\%) meninggal sebelum 28 hari (Tabel 1).

Analisis perbedaan antara dua kelompok dengan analisis korelasi pada data numerik dan analisis Chi Square dengan data kategorikal menunjukkan tidak ada perbedaan karakteristik yang bermakna, sehingga kedua kelompok berimbang (matched) seperti yang terlampir pada Tabel 1 .

Penjaminan mutu MPV dan hitung trombosit menggunakan alat Hemato analyzer Cell-dyn Abbott@ menunjukkan alat terkontrol saat masa penelitian (November 2019 sampai Februari 2020). Pengecekan flagging, delta check, dan konfirmasi hapusan darah tepi dilakukan untuk memastikan hasil yang dikeluarkan valid. Sementara itu, hasil uji impresisi kit IL-6 didapatkan SD sebesar 3,708 pg/mL dan CV sebesar 2,6\%. Nilai ini dibawah nilai maksimal SD dan CV yang diperbolehkan alat untuk bekerja, menandakan pemeriksaan IL-6 dapat dijalankan.

Karakteristik hasil laboratorium didapatkan ratarata MPV sebesar 7,11 fL, rata-rata hitung trombosit sebesar $218.511 \mathrm{sel} / \mu \mathrm{L}$, rata-rata rasio $\mathrm{MPV} /$ PLT sebesar 5,404, dan rata-rata kadar IL-6 sebesar 215,32 pg/mL. rata-rata MPV dan kadar IL-6 secara bermakna lebih tinggi pada kelompok risiko tinggi dibandingkan dengan kelompok risiko rendah. Rata-rata hitung trombosit secara bermakna lebih rendah pada kelompok risiko tinggi dibandingkan dengan kelompok risiko rendah. Hasil observasi selama 28 hari didapatkan kejadian kematian lebih tinggi pada kelompok berisiko tinggi dibandingkan dengan kelompok risiko rendah.

Analisis Receiver Operating Curve (ROC) dilakukan untuk mencari nilai titik potong atau cut-off dalam analisis kesintasan prediktor awal kematian melalui penilaian parameter MPV, hitung trombosit, dan rasio MPV/PLT. Hasil penelitian menunjukkan bahwa nilai cut-off baik pada MPV (6,745; AUC: 0,650), hitung trombosit (182.150; AUC:

Tabel 1 Karakteristik sampel penelitian

\begin{tabular}{|c|c|c|c|c|}
\hline Parameter & $\begin{array}{c}\text { Semua subjek } \\
(n=54)\end{array}$ & $\begin{array}{l}\text { Kelompok berisiko tinggi } \\
(n=27)\end{array}$ & $\begin{array}{c}\text { Kelompok berisiko } \\
\text { rendah }(n=27)\end{array}$ & $P$ \\
\hline Umur (hari) & $3.46 \pm 7.065$ & $2,48 \pm 6,13$ & $4,44 \pm 7,89$ & 0,323 \\
\hline \multicolumn{5}{|l|}{ Jenis kelamin, n (\%) } \\
\hline Laki-laki & $39(72,22)$ & $19(70,37)$ & $20(74,07)$ & \multirow[t]{2}{*}{0,76} \\
\hline Perempuan & $15(27,78)$ & $8(29,63)$ & $7(25,93)$ & \\
\hline \multicolumn{5}{|l|}{ Jenis sepsis, n (\%) } \\
\hline SNAD & $48(88,89)$ & $25(92,59)$ & $23(85,19)$ & \multirow[t]{2}{*}{0,334} \\
\hline SNAL & $6(11,11)$ & $2(7,41)$ & $4(14,81)$ & \\
\hline Berat lahir (gram) & $2.126,6 \pm 794,1$ & $1.875,5 \pm 794,1$ & $2.377,5 \pm 1016,3$ & 0,083 \\
\hline \multicolumn{5}{|l|}{ Frekuensi Berat lahir, n (\%) } \\
\hline Normal ( $\geq 2500$ gram) & $21(38,89)$ & $6(22,22)$ & $15(55,54)$ & \multirow[t]{6}{*}{0,05} \\
\hline BBLR (1500 - 2499 gram) & $15(27,78)$ & $11(40,74)$ & $4(14,82)$ & \\
\hline BBLSR (1000 - 1499 gram) & $10(18,51)$ & $6(22,22)$ & $4(14,82)$ & \\
\hline BBLASR $(<1000$ gram $)$ & $8(14,81)$ & $4(14,82)$ & $4(14,82)$ & \\
\hline Bayi Prematur, n (\%) & $33(61,11)$ & $20(74,07)$ & $13(48,14)$ & \\
\hline MPV (fL) & $7,11 \pm 1,85$ & $8,05 \pm 2,09$ & $6,18 \pm 0,86$ & \\
\hline Hitung trombosit $(\mathrm{sel} / \mu \mathrm{L})$ & $218.511 \pm 121.085$ & $122.626 \pm 56.243$ & $314.39 \pm 87.344$ & 0,000 \\
\hline Rasio MPV/PLT & $5,404 \pm 5,351$ & $8,66 \pm 5,98$ & $2,14 \pm 0,75$ & 0,000 \\
\hline Kadar IL-6 (pg/mL) & $215,32 \pm 444,48$ & $351,91 \pm 580,22$ & $78,72 \pm 165,25$ & 0,000 \\
\hline Meninggal dalam 28 hari, $n$ (\%) & $7(12,96)$ & $6(22,22)$ & $1(3,7)$ & 0,030 \\
\hline
\end{tabular}


Tabel 2 Analisis dengan kurva ROC

\begin{tabular}{lccccc}
\hline Parameter & Cut-off & Sensitivitas & Spesifisitas & AUC & $\boldsymbol{p}$ \\
\hline MPV & 6,745 & $85,7 \%$ & $57,4 \%$ & 0,650 & 0,202 \\
Hitung Trombosit & 182.150 & $42,9 \%$ & $59,6 \%$ & 0,301 & 0,092 \\
Kadar IL-6 & 90,25 & $71,4 \%$ & $74,5 \%$ & 0,713 & 0,071 \\
Rasio MPV/PLT & 3,73 & $85,7 \%$ & $57,4 \%$ & 0,690 & 0,108 \\
\hline
\end{tabular}

Tabel 3 Analisis korelasi Spearman antara MPV/PLT, MPV, kadar IL-6, dan hitung trombosit

\begin{tabular}{lcc}
\hline Parameter & $\mathbf{r}$ & $\mathbf{p}$ \\
\hline Kadar IL-6 & & \\
Rasio MPV/PLT & 0,252 & $>0,05$ \\
MPV & 0,286 & $>0,05$ \\
Hitung Trombosit & & \\
MPV & $-0,229$ & $>0,05$ \\
Hitung Trombosit & $-0,492$ & $<0,05$ \\
\hline
\end{tabular}

Tabel 4 Analisis kesintasan parameter MPV, Hitung Trombosit, kadar IL-6, dan rasio MPV/ PLT

\begin{tabular}{lccc}
\hline Parameter & Cut-off & Hazard ratio & P \\
\hline MPV & 6,745 & 4,535 & 0,033 \\
Hitung Trombosit & 182.150 & 0,686 & 0,408 \\
Kadar IL-6 & 90,25 & 6,361 & 0,012 \\
Rasio MPV/PLT & 3,73 & 4,535 & 0,033 \\
\hline
\end{tabular}

0,301), kadar IL-6 (90,25; AUC: 0,713), maupun rasio MPV/PLT (3,73; AUC: 0,690) menunjukkan hubungan tidak bermakna secara statistik $(\mathrm{p}>0,05)$ sebagai prediktor awal kematian pada sepsis neonatal (Tabel 2).

Analisis korelasi Spearman menyatakan tidak ada korelasi antara kadar IL-6 dengan rasio MPV/ PLT dengan nilai $r=0,252 \quad(p>0,05)$. Selain itu, tidak ada korelasi antara kadar IL-6 dengan MPV $(\mathrm{r}=0,286$ dengan $p>0,05)$ dan hitung trombosit $(r=-0,229$ dengan $p>0,05)$. Sementara itu, terdapat korelasi negatif yang lemah namun bermakna antara MPV dengan hitung trombosit, dengan korelasi sebesar $\mathrm{r}=-0,492(p<0,05)$ (Tabel 3).

Berdasarkan analisis kesintasan dengan analisis Hazard Ratio (HR), ditemukan bahwa variabel MPV (HR: 4,535; p=0,033), kadar IL-6 (HR: 6,361; $\mathrm{p}=0,012$ ), dan rasio MPV/PLT (HR: 4,535; $\mathrm{p}=0,033)$ secara bermakna dapat menjadi prediktor kematian dalam 28 hari pada sepsis neonatal seperti yang ditunjukkan pada Tabel 4 .

\section{PEMBAHASAN}

Karakteristik subyek penelitian ini menunjukkan sebanyak $61,11 \%$ neonatus memiliki berat lahir kurang dari 2500 gram dan sebanyak 31,48\% memiliki berat lahir kurang dari 1500 gram. Kejadian kematian sebesar 12,96\% dengan karakteristik subyek yaitu $100 \% \mathrm{SNAD}<85,71 \%$ prematur, dan 71,42\% dengan berat lahir kurang dari 2500 gram. Karakteristik ini sesuai dengan risiko kematian yang meningkat pada bayi berat lahir rendah, prematur dan SNAD. ${ }^{13}$

Peningkatan kadar IL-6 terjadi pada semua subyek penelitian dengan rata-rata $215,32 \mathrm{pg} / \mathrm{mL}$ dimana pada penelitian sebelumnya menunjukkan bahwa kadar normal IL-6 pada neonatus yaitu $0-16,4 \mathrm{pg} / \mathrm{mL} .{ }^{14} \mathrm{Hal}$ ini dapat terjadi karena semua subyek penelitian ini mengalami kondisi sepsis. Rata-rata kadar IL-6 pada kelompok risiko tinggi lebih tinggi dibandingkan dengan kelompok risiko rendah.

Hasil penelitian ini menyatakan MPV yang tinggi merupakan prediktor awal kematian dalam 28 hari pada pasien sepsis neonatal. Pasien sepsis neonatal dengan MPV diatas $6,745 \mathrm{fL}$ saat diagnosis klinis sepsis neonatal ditegakkan memiliki risiko kematian sebesar 4,535 kali lebih tinggi dalam 28 hari. ${ }^{15}$ Penelitian ini mendukung penelitian sebelumnya pada bayi prematur oleh Shaaban dan Safwat. ${ }^{15}$ Namun hasil ini bertentangan dengan studi sebelumnya yang menyatakan MPV saja di awal tidak dapat digunakan sebagai prediktor 
kematian pada pasien sepsis dewasa. ${ }^{8}$ Justru perubahan MPV antara hari pertama dengan beberapa hari berikutnya, misalnya 72 jam, secara bermakna dapat berperan sebagai prediktor kematian.9,16

Hitung trombosit yang rendah bukan merupakan prediktor awal kematian dalam 28 hari pada pasien sepsis neonatal menurut penelitian ini. Hasil inipun didukung oleh beberapa penelitianpenelitian sebelumnya yang menunjukkan bahwa trombosit yang rendah bukan merupakan prediktor awal kematian pada pasien sepsis neonatal., ${ }^{9,16,17}$ Alasannya, hitung trombosit yang diperiksa satu kali saja saat awal penyakit belum mampu menggambarkan respon tubuh terhadap inflamasi karena sepsis. Justru trombositopenia yang tidak mengalami perbaikan dalam perjalanan penyakit, berhubungan dengan peningkatan kematian dalam 28 hari. ${ }^{17}$ Disamping itu, penggunaan cut-off yang lebih rendah juga lebih bermakna dalam menentukan prognosis pada pasien sepsis. ${ }^{16}$

Rasio MPV/PLT yang tinggi, baik menggunakan cut off penelitian sebelumnya $(3,71)$ atau penelitian ini $(3,73)$, merupakan prediktor awal kematian dalam 28 hari pada pasien sepsis neonatal. Pasien sepsis neonatal dengan rasio MPV/PLT diatas 3,73 saat diagnosis klinis sepsis neonatal ditegakkan memiliki risiko kematian sebesar 4,085 kali lebih tinggi dalam 28 hari dimana didukung oleh enelitian sebelumnya. ${ }^{9}$ Rasio MPV/PLT termasuk rumus variasinya, seperti PLT/MPV, telah dipelajari memiliki potensi untuk digunakan sebagai marker dalam penyakit sepsis. ${ }^{18,19} \mathrm{Hal}$ ini disebabkan karena adanya korelasi negatif antara MPV dengan hitung trombosit yang juga dibuktikan pada penelitian ini. ${ }^{19,20}$ Peningkatan MPV berhubungan dengan adanya trombosit imatur dan aktivasi trombosit di perifer. ${ }^{20,21}$ Trombosit imatur dan trombosit yang aktif di perifer cenderung mengalami penurunan paruh hidup berhubungan dengan pemakaiannya yang berlebihan pada sepsis, menyebabkan jumlahnya yang menurun atau trombositopenia. ${ }^{17,22}$ Korelasi negatif yang lemah pada penelitian ini bisa disebabkan oleh faktor-faktor lain yang mempengaruhi MPV dan trombosit, seperti faktor genetik, usia, ras dan etnis, serta diet. ${ }^{23}$

Tidak ada korelasi antara rasio MPV/PLT dengan IL-6 pada pasien sepsis neonatal walaupun kadar IL-6 secara bermakna lebih tinggi pada kelompok risiko tinggi dibandingkan dengan kelompok risiko rendah dan dapat digunakan sebagai prediktor kematian dalam sepsis neonatal. Hal ini kemungkinan disebabkan karena efek IL-6 pada trombosit yang tidak langsung dan memerlukan waktu. Interleukin-6 dapat merangsang thrombopoiesis melalui perangsangan hormon thrombopoietin dan meningkatkan aktivasi trombosit melalui mekanisme asam arakhidonat. ${ }^{4,5}$ Selain itu, trombosit sendiri dapat memberikan efek meningkatkan atau menurunkan kadar IL- $6 .{ }^{24,25}$

Keterbatasan penelitian ini adalah tidak melakukan penilaian terhadap perubahan nilai MPV $(\triangle \mathrm{MPV})$ dan hitung trombosit $(\triangle \mathrm{PLT})$ selama perawatan pasien dengan sepsis neonatal. Kesulitan lain penelitian ini adalah beberapa sampel darah untuk pemeriksaan trombosit dan IL-6 tidak diambil bersamaan. Perbedaan waktu ini akan mempengaruhi hasil IL-6 karena waktu paruh yang singkat yaitu 2-15 jam. ${ }^{26,27}$ Keterbatasan lain adalah cut off MPV yang didapatkan dari penelitian ini hanya bisa diterapkan pada pemeriksaan yang menggunakan hemato analyzer yang digunakan peneliti. Hal ini dikarenakan belum ada standardisasi besar MPV dari masing-masing hemato analyzer, belum ada kalibrator eksternal, dan metode yang digunakan masing-masing alat berbeda. ${ }^{28}$

\section{SIMPULAN}

Hasil penelitian ini menunjukkan bahwa beberapa parameter seperti rasio MPV/PLT dan MPV secara statistik bermakna dapat digunakan sebagai prediktor awal kematian dalam 28 hari pada pasien dengan klinis sepsis neonatal di RSUP Sanglah, Bali, Indonesia.

\section{KONFLIK KEPENTINGAN}

Tidak ada.

\section{PERSETUJUAN ETIK}

Penelitian ini telah disetujui oleh Komisi Etik Penelitian Fakultas Kedokteran Universitas Udayana/Rumah Sakit Umum Pusat Sanglah Denpasar.

\section{PENDANAAN}

Tidak ada.

\section{KONTRIBUSI PENULIS}

Seluruh penulis memiliki kontribusi yang sama dalam penulisan laporan penelitian ini baik dari tahap penyusunan kerangka konsep, pengumpulan data, analisis data penelitian, hingga pelaporan hasil penelitian dalam bentuk publikasi ilmiah.

\section{DAFTAR PUSTAKA}

1. Shane AL, Sánchez PJ, Stoll BJ. Neonatal sepsis. Lancet. 2017;390(10104):1770-1780

2. UNICEF. Maternal and Newborn Health Disparities: Indonesia. Unicef for every child. 2017; 1-7. 
3. Putra PJ. Insiden dan Faktor-Faktor yang Berhubungan dengan Sepsis Neonatus di RSUP Sanglah Denpasar. Sari Pediatri. 2012;14(3):205-10

4. Oleksowicz L, Mrowiec Z, Zuckerman D, Isaacs R, Dutcher J, Puszkin E. Platelet activation induced by interleukin-6: evidence for a mechanism involving arachidonic acid metabolism. Thromb Haemost. 1994;72(2):302-308.

5. Senchenkova EY, Komoto S, Russell J, Almeida-Paula LD, Yan LS, Zhang S, et al. Interleukin-6 mediates the platelet abnormalities and thrombogenesis associated with experimental colitis. Am J Pathol. 2013;183(1):173-181.

6. Claushuis TA, van Vught LA, Scicluna BP, Wiewel MA, Klouwenberg PMCK, Hoogendijk AJ, etal. Thrombocytopenia is associated with a dysregulated host response in critically ill sepsis patients. Blood. 2016;127(24):3062-3072.

7. Gao Y, Li Y, Yu X, Guo S, Ji X, Sun T, et al. The impact of various platelet indices as prognostic markers of septic shock. PLoS One. 2014;9(8):e103761.

8. Kim CH, Kim SJ, Lee MJ, Kwon YE, Kim YL, Park KS, et al. An increase in mean platelet volume from baseline is associated with mortality in patients with severe sepsis or septic shock. PLoS One. 2015;10(3):e0119437.

9. Oh GH, Chung SP, Park YS, et al. Mean Platelet Volume to Platelet Count Ratio as a Promising Predictor of Early Mortality in Severe Sepsis. Shock. 2017;47(3):323-330.

10. Kaushik R, Gupta M, Sharma M, Jash D, Jain N, Sinha N, et al. Diagnostic and Prognostic Role of Neutrophil-toLymphocyte Ratio in Early and Late Phase of Sepsis. Indian J Crit Care Med. 2018;22(9):660-663.

11. Prabawa IPY, Bhargah A, Liwang F, Tandio DA, Tandio AL, Lestari AAW, et al. Pretreatment Neutrophilto-Lymphocyte ratio (NLR) and Platelet-to-Lymphocyte Ratio (PLR) as a Predictive Value of Hematological Markers in Cervical Cancer. Asian Pac J Cancer Prev. 2019;20(3):863-868.

12. Dharma BDA, Mulyantari NK, Prabawa IPY. Analisis korelasi kadar serum prokalsitonin dengan jumlah leukosit pada penderita dengan kecurigaan sepsis di RSUP Sanglah, Bali, Indonesia. Intisari Sains Medis. 2020;11(1):179-182.

13. Simonsen KA, Anderson-Berry AL, Delair SF, Davies HD. Early-onset neonatal sepsis. Clin Microbiol Rev. 2014;27(1):21-47.

14. Khan A, Ali Z. Normal Ranges for Acute Phase Reactants (Interleukin-6, Tumour Necrosis Factor-alpha and C-reactive Protein) in Umbilical Cord Blood of Healthy Term Neonates at the Mount Hope Women's Hospital, Trinidad. West Indian Med J. 2014;63(5):465-469.

15. Shaaban HA, Safwat N. Mean platelet volume in preterm: a predictor of early onset neonatal sepsis. J Matern Fetal Neonatal Med. 2020;33(2):206-211.

16. Tajarernmuang P, Phrommintikul A, Limsukon A, Pothirat C, Chittawatanarat K. The Role of Mean Platelet Volume as a Predictor of Mortality in Critically Ill Patients: A Systematic Review and Meta-Analysis. Crit Care Res Pract. 2016;2016:4370834.
17. Venkata C, Kashyap R, Farmer JC, Afessa B. Thrombocytopenia in adult patients with sepsis: incidence, risk factors, and its association with clinical outcome. J Intensive Care. 2013;1(1):9.

18. Ates S, Oksuz H, Dogu B, Bozkus F, Ucmak H, Yanıt F. Can mean platelet volume and mean platelet volume/platelet count ratio be used as a diagnostic marker for sepsis and systemic inflammatory response syndrome?. Saudi Med J. 2015;36(10):1186-1190.

19. Tamelytė E, Vaičekauskienẻ G, Dagys A, Lapinskas T, Jankauskaite L. Early Blood Biomarkers to Improve Sepsis/ Bacteremia Diagnostics in Pediatric Emergency Settings. Medicina (Kaunas). 2019;55(4):99.

20. Burstein SA, Downs T, Friese P, Lynam S, Anderson S, Henthorn J, et al. Thrombocytopoiesis in normal and sublethally irradiated dogs: response to human interleukin-6. Blood. 1992;80(2):420-428.

21. Braekkan SK, Mathiesen EB, Njølstad I, Wilsgaard T, Størmer J, Hansen JB. Mean platelet volume is a risk factor for venous thromboembolism: the Tromsø Study, Tromsø, Norway. J Thromb Haemost. 2010;8(1):157-162.

22. Greinacher A, Selleng S. How I evaluate and treat thrombocytopenia in the intensive care unit patient. Blood. 2016;128(26):3032-3042.

23. Korniluk A, Koper-Lenkiewicz OM, Kamińska J, Kemona H, Dymicka-Piekarska V. Mean Platelet Volume (MPV): New Perspectives for an Old Marker in the Course and Prognosis of Inflammatory Conditions. Mediators Inflamm. 2019;2019:9213074.

24. Kral JB, Schrottmaier WC, Salzmann M, Assinger A. Platelet Interaction with Innate Immune Cells. Transfus Med Hemother. 2016;43(2):78-88. doi:10.1159/000444807

25. Linke B, Schreiber Y, Picard-Willems B, Slattery P, Nusing RM, Harder S, et al. Activated Platelets Induce an Anti-Inflammatory Response of Monocytes/Macrophages through Cross-Regulation of $\mathrm{PGE}_{2}$ and Cytokines. Mediators Inflamm. 2017;2017:1463216.

26. Wirtz DC, Heller KD, Miltner O, Zilkens KW, Wolff JM. Interleukin-6: a potential inflammatory marker after total joint replacement. Int Orthop. 2000;24(4):194-196.

27. Marino A, Giotta N. Cinacalcet, fetuin-A and interleukin-6. Nephrol Dial Transplant. 2008;23(4):1460-1462.

28. Noris P, Melazzini F, Balduini CL. New roles for mean platelet volume measurement in the clinical practice? Platelets. 2016;27(7):607-612.

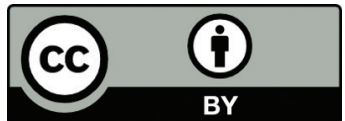

This work is licensed under a Creative Commons Attribution 